\title{
イバラガニモドキ（新称）について
}

\author{
插図 1
}

久保伊津男池ノ上 宏

(東京水産大学)

\section{SOME NOTES ON AN ANOMURAN CRAB, LITHODES AEQUISPINA}

With 1 Text-figure

\section{ITSUO KUBO and HIROSHI IKENOUE}

(Tokyo University of Fisheries)

イバラガニモドキ Lithodes aequispina(a) Bnedict (1894) はタラバガニ科 (Lithodidae）のカニであるが, 昭和38年 (12月) ごろから塩屋岬沖で漁獲されている。福島県磐 城市 (小名浜) では, 通称イワキガニと称して一般に賞味されている。肉はタラバガニに おとらず，きわめて美味である。小名浜魚市場への水揚量は年によって相違するよらであ るが, 年間10１5トン程度である。就業漁船数も年によって変るが, 多い年は 7 隻位に達 する。本篇ではこのカニの形態, 生態, 漁業等についてのべる。

本文に入る前に, このカ二の上記のような事柄を調查するのに種々御援助, 御協力をい ただいた福島県水産試験場長星正二氏, 同場資源部長秋元義正氏, 浜屋漁業部の高木正恭 氏に深甚の謝意を表する。またこの調査に御協力されるとともに, 写真の製作に多大の力 をかされた東京水産大学助教授高木和徳博士に深かく謝意を表する。

\section{記載}

頭胸甲はタラバガニ科のカニであるから, ほぼ西洋梨形で多数の棘を有する。その全棘 数(b)は $111 \sim 161^{(\mathrm{c})}$ である。胃域に15棘余, 心域に 6 棘, あるいは 8 棘, 腸域に 3 棘を有す る。額角はあまり長くなく, ふつう背面に 2 棘, 各側縁に各 2 棘, 先端に 2 棘, および腹 面基部に 1 棘, 合計 9 棘 $(2,3)$ を有する。成体では甲幅は甲長よりるわずかに大きい。この 傾向はとくに雄において強い（表 1 )。第 2 触角鱗片の先端には, ふつう大, 小 2 䊂を有 し，前棘が大きく後棘が小さい（図 $1, \mathrm{~A}$ )。

生時の体色は赤褐色である。

卵(d) は球形飞近い楕円形で, 長径, 短径それぞれ約 $1.1,0.9 \mathrm{~m} m$ である。生時の色は多 少赤味をおびたうすい橙色である。

(a) aequi は equi と同意である。 (b) 側面, 縁の棘㧍よび大, 小の総棘数。

(c) 3 個体しらべた結果。 (d) 生の卵を薄い塩漬にすると美味である。 
Table 1. Carapece length(L), carapece width $(\mathrm{W})$ and $\mathrm{W} / \mathrm{L}$ of Lithodes aequispina obtained from waters off Shioyazaki, Fukushima Pref. Unit, cm. 塩屋岬沖産イバラ ガニモドキの頭胸甲長 $(L)$, 頭胸甲幅 $(W)$, 拈よ びW/L, 長さの単位 $\mathrm{cm}$.

\begin{tabular}{rrrl|rrrr}
\hline \multicolumn{3}{c|}{} & \multicolumn{5}{|c}{ 早 } \\
\hline No. & L & W & W/L & No. & L & W & W/L \\
\hline 1 & 4.7 & 4.3 & 0.92 & 1 & 11.7 & 12.2 & 1.04 \\
2 & 6.1 & 5.9 & 0.97 & 2 & 13.2 & 13.9 & 1.05 \\
3 & 6.7 & 6.5 & 0.97 & 3 & 13.3 & 13.6 & 1.02 \\
4 & 8.2 & 8.2 & 1.00 & 4 & 13.3 & 13.8 & 1.04 \\
5 & 8.9 & 8.6 & 0.96 & 5 & 14.0 & 14.7 & 1.05 \\
6 & 9.0 & 8.8 & 0.98 & 6 & 14.4 & 15.1 & 1.05 \\
7 & 9.4 & 9.6 & 1.02 & 7 & 14.6 & 14.8 & 1.01 \\
8 & 9.4 & 9.7 & 1.03 & 8 & 15.5 & 16.8 & 1.08 \\
9 & 9.5 & 9.5 & 1.00 & & & & \\
10 & 9.5 & 9.5 & 1.00 & & & & \\
11 & 9.8 & 9.7 & 0.99 & & & & \\
12 & 11.2 & 11.3 & 1.01 & & & & \\
13 & 11.5 & 11.5 & 1.00 & & & & \\
14 & 12.0 & 12.2 & 1.01 & & & & \\
\hline
\end{tabular}

分布 従来, Bering 海, 184 406英尋 (Benedict, 1894) ; British Columbia 沖 150 200 英尋 (275～ 366m) (Butler and Hart, 1962) などから知られている。オホーック 海では, 南部カムチャッカ西方水深 300 600mの海域で漁獲される。本 邦近海では塩屋岬沖 N E, 距岸約 40 哩, 水深約 $500 \mathrm{~m}$ 付近で漁獲される。 な秃業者の談によると, 金華山沖 $\mathrm{S} \mathrm{E}$, 距岸30 40哩, 水深500 600 mの海域でも本種の漁獲があるとい われている。

漁法 塩屋岬沖, オホーツク海で はカニ籠によって漁獲される。塩屋 岬沖では漁獲に北洋漁業のサケ, マ 又漁業の独航船96トン型鉄船が使用 されている。塩屋岬沖で使われてい るカ二籠は口径 $45 \mathrm{~cm}$ 位, 底径 120 $\mathrm{cm}$ 位, 高さ $58 \mathrm{~cm}$ 位で, これに約 10 mの口紐をつけてある。カ二籠 1 張

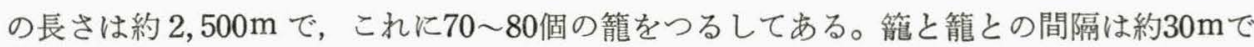
ある。籠の中には各籠 2 個ずつ円筒形べークライト製の餌筒がつるしてある。その大きさ は高さ $10 \mathrm{~cm}$, 径 $7 \mathrm{~cm}$ である。その壁面には多数の小孔（径 $1 \mathrm{~mm}$ 位）が付してある。餌 にはサンマ, サバ，カタクチイワシなどを用い，大形魚は適当な大きさに切断して餪筒の 中に入れ，カタクチイワシなどはそのまま入れる。

磐城では籠を朝 4 〜 時ごろ海底に投入してその夕方漁獲するものもあり，あるいは何 日かたってから漁獲するものもある。

漁期 漁期は長い。磐城では船によって約10ヶ月（12月～9 月）出漁する。比較的漁の 多いのは11月〜 6 月で, 最も漁の多いのは 2 月〜 3 月である。 1 月〜 2 月ごろ, 水深 460 〜 490m 程度のところでは雄の大きいのがとれ，3 月になって雌雄混獲される。このころ の雌には抱卵しているるのがみられる。

漁場 塩屋岬沖では漁場は水深 $450 \mathrm{~m}$ 位のところから形成されるが，この付近では海底 部は岩石である。この付近ではほとんど雄だけが漁獲される。これよりも少し樑い場所で は反対にほとんど雌だけが漁獲される。雌が漁獲される場所の底質は砂, あるいは泥のよ うである。金華山沖でも同様な棲分け現象がみられるようで, 水深500～600mのところで は漁獲されるカニの $90 \%$ 以上が雌であるといわれている。抱卵した雌は水深700〜 740m, 砂底質で所々に岩石のあるような海域に多いといわれている。 


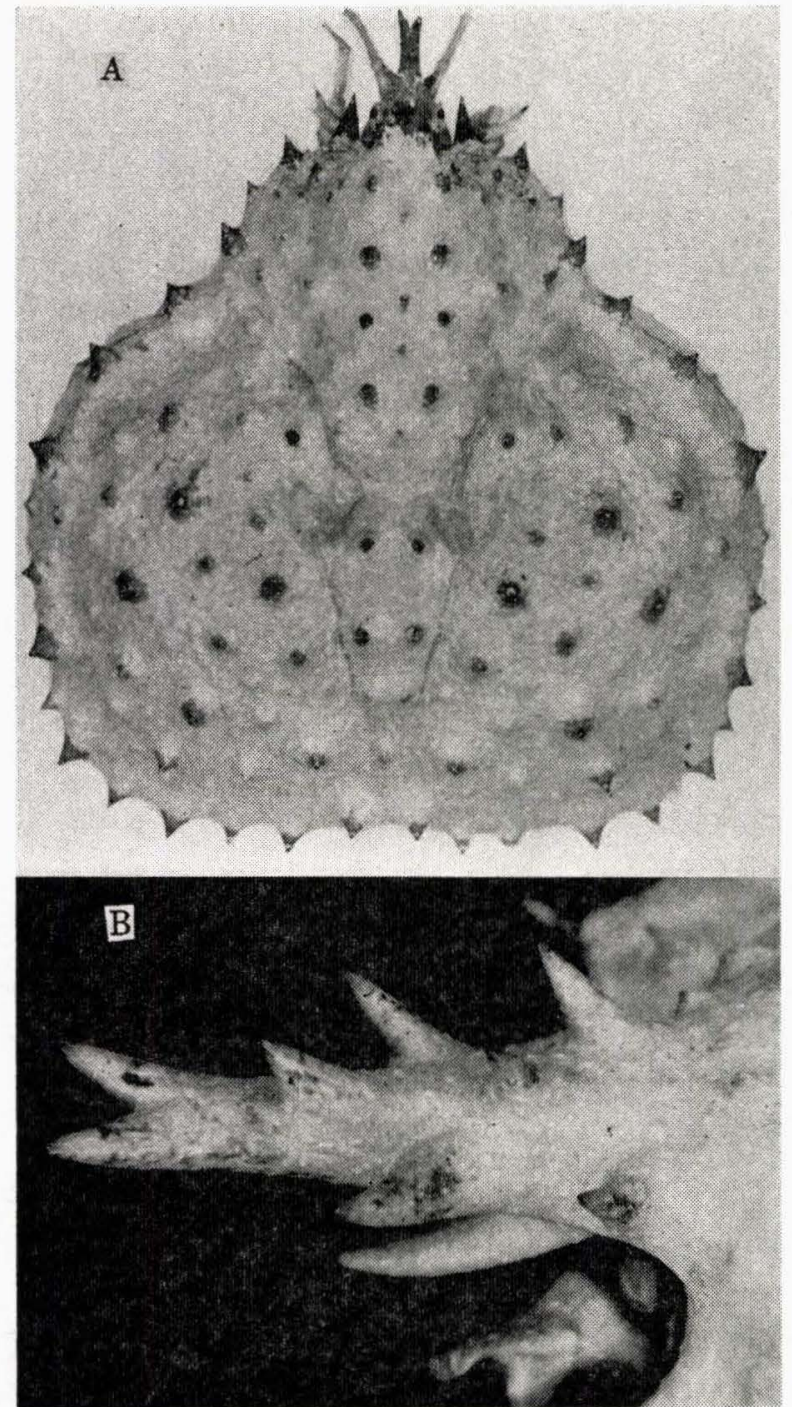

Fig. 1. Lithodes aequispina. A, carapace of male, $160 \mathrm{~mm}$ in length; $B$, rostrum (26mm from tip of spine to base of the rostrum), carapace length, $112 \mathrm{~mm}$. イバラガニモドキ. A, 雄 の頭胸甲 (長さ $160 \mathrm{~mm}$ ) ; B ，頭胸甲長 $112 \mathrm{~mm}$ の 個体の額角（基部から棘の先端までの長さ $26 \mathrm{~mm}$ ).
論

議

本種は形態的にイ バラガ ニ (4 6) (俗にアカガニ) Lithodes turritus Ortman (1892) に きわめて近似しているが, 額角 の形態が著しく相違しているの で容易に識別される。イバラガ ニは学名が示すように額角が塔 状で長く, 腹面基部の 1 棘を加 えて 5 棘を有するが，イバラガ 二モドキでは額角が比較的短か く, 前記のように腹面基部の 1 棘を加えて 9 棘, あるいは10棘 である。またこの両種では分布 が異るようである。イバラガニ モドキは北太平洋, ベーリング 海, オネーツク海に広く分布し ているよらであるが, イバラガ 二は相模湾(4 6) $(600 \mathrm{~m})^{(1)}$, 土 佐湾の深所 $(300 \sim 600 \mathrm{~m})^{(5)}$ から 知られているのみである。

頭胸甲背面の全棘数には大形 個体では少なく，小形個体では 多い傾向が存在するようであ る。3 個体しらぺた結果では, 甲長 $160 \mathrm{~mm}$ のものでは 111 棘, $112 \mathrm{~mm}$ のものでは 136 棘, 85 $\mathrm{mm}$ のものでは 161 棘である。 額角背面の棘は多くの場合 2 棘 であるが，ときに 3 棘の場合が ある。したがって背面の棘数が 3 棘の場合は, 総棘数は10棘で ある。第 2 触角鱗片先端の棘数は, Butler and Hart（1962）によると 3 棘の場合もあ るようであるが, 3 棘のものはきわめて少ない。

雄では, 比較的若い個体は得られていないので不明であるが, 雌で頭胸甲長 $9 \mathrm{~cm}$ 程度 のもの以下の小さい個体では，甲長は甲幅よりも大きい場合が多い傾向がみられる。甲長 が $9 \mathrm{~cm}$ 以上の大きい雌では, 甲長と甲幅はほぼ等しいか, あるいは甲幅が甲長よりもわ 
ずかに大きい。甲長 11.7 15. $5 \mathrm{~cm}$ の範囲の雄では，つねに甲長よりも甲幅がわずかに大 きい(表 1 )。

\section{文献}

(1) Balss, H. 1913 Ostasiatische Decapoden 1. (Die Galatheiden und Paguriden). Abhandlungen der math. - phys. Klasse der K. Bayer. Akademie der Wissenschaften 2. Suppl. - Bd. 9. Abhandlg., pp. $1 \sim 85$, Taf. $\mathrm{I} \sim$ II .

(2) Benedict, J. E. 1894 Description of new genera and species of crabs of the family Lithodidae, with notes on the young of Lithodes camtschaticus and Lithodes brevipes. Proc. U. S. Nat. Museum, 17 (1016) $479 \sim 488$.

(3) Butler, T. H. and F. L. Hart 1962 The occurrence of the king crab Paralithodes camtschtica (Tilesius) and of Lithodes aequispina Benedict in British Columbia. J. Fish. Res. Bd. Canada, 19 (3) 401 408.

（4）中 沢 毅 一 1927 日本動物図鑑，p. 1048, fig. 2019；1954 (第13版), p. 732, fig. 2117. 北隆館 (東京).

(5). 三 宅 貞 祥 1965 新日本動物図鑑 (中), p. 651, fgi. 1110. 北隆館 (東京).

(6) Ortmann, A. 1892 Die decapoden Krebse des Strassburger Museums 4. Zoolngische Jahrbücher, Abteilung für Systematik, 6:320 321, Tab. 12 , fig. 26 .

\section{Résumé}

A new locality is found from Japan on the crab, Lithodes aequispina Benedict (1894). This crab has been taken from waters, $450 \sim 740 \mathrm{~m}$ in depth, off Shioyazaki, Fukushima Prefecture. The crab in question is characterized by the rostrum, which is armed with 9 (Fig. 1B) or 10 spines. Sometimes 3 spines are found on the dorsal surface of the rostrum, when the spines of the rostrum enumerate 10 spines in total number. The carapace furnished with 111 161 acute short spines (Fig. 1A). This spines have a trend decreasing in number with growth. An individual, $85 \mathrm{~mm}$ in carapace length, bears 161 spines, that, $112 \mathrm{~mm}$ long, has 136 spines, and that, $160 \mathrm{~mm}$ long, has 111 ones.

In adult form, the width of the carapace is larger than the length of the carapace. This inclination seems to be a little more salient in male than in female as shown in the Table 1 .

The egg of this crab is comparatively lager, measuring ca. $1.1 \mathrm{~mm}$ in longer diameter, ca. $0.9 \mathrm{~mm}$ in shorter one. 
Fishery of this crab, in Iwaki city, Fukushima Pref., takes place during the months from December to September. Vigorous season ranges from January to March. Some females taken in March are found bearing eggs beneath abdomen. This crab is fished by using a cage about $45 \mathrm{~cm}$ and $120 \mathrm{~cm}$ in diameter of the mouth and the bottom respectively, about $58 \mathrm{~cm}$ in height. Some fishes, such as scomber, saury, sardine, anchovy, and others are used for the bait. 